\title{
RBEP
}

\section{Formação continuada de professores a distância: o desvelamento de focos de estudo expressos em produções acadêmicas}

\author{
Marta Lyrio da Cunha \\ Lúcia Regina Goulart Vilarinho
}

\begin{abstract}
Resumo
Focaliza a produção acadêmica relativa à formação continuada a distância de professores, tendo como objetivos específicos: a) determinar seus focos de estudo; b) identificar as questões mais recorrentes; e c) estabelecer os subsídios oferecidos para o desenvolvimento de propostas nesta área. A pesquisa, caracterizada como estudo documental, incidiu sobre os periódicos nacionais classificados pela Qualis/Capes na categoria qualidade A, incluindo, também, os trabalhos apresentados nas reuniões anuais da ANPEd e os publicados pela Revista Brasileira de Tecnologia Educacional. Ao todo, foram analisados 37 trabalhos publicados no período 2000-2004. Também, baseou-se em orientações da técnica de Análise de Conteúdo, a partir das quais foi possível organizar o corpus do estudo e proceder aos diferentes tipos de leitura indispensáveis a uma proposta dessa natureza, a saber: préanálise, leitura exploratória, leitura interpretativa e leitura conclusiva. Os dados coletados foram analisados à luz da perspectiva que situa a formação de professores como prática reflexiva. A investigação evidenciou que: o foco políticas públicas é o mais proeminente no âmbito dessa produção; entre as questões mais recorrentes destaca-se a preocupação com políticas aligeiradas de formação a distância e certificação em escala; são significativas as contribuições para subsidiar a implementação e/ou reformulação de propostas de formação continuada a distância de professores.
\end{abstract}


Palavras-chave: formação continuada de professores; educação a distância; perspectiva reflexiva.

\section{Abstract \\ Continued formation of teachers in distance learning: study focus expressed in academic productions}

The paper focuses the academic production related to the continued formation of teachers, having as main objectives the following: a) to determine its focus of study; b) to identify the most recurrent questions; and c) to establish the subsidies offered for the development of proposals in this area. The research, characterized as a documentary study, was presented on national journals classified by Qualis/Capes as "quality A" (top quality), including, also, the works presented in the annual meetings of ANPEd and the ones published by Revista Brasileira de Tecnologia Educacional (Brazilian Magazine of Educational Technology). Altogether, 37 works published during 2000-2004 were analyzed. Also, the research was based on orientations of the technique of Content Analysis, from which it was possible to organize the corpus of the study and to proceed to the different indispensable types of reading to a proposal of this nature, i.e.: previous analysis, exploratory reading, interpretative reading and conclusive reading. The collected data had been analyzed regarding the perspective that points out the formation of teachers as a reflexive practice. The inquiry evidenced that: the focus "public policies" is most prominent in the scope of this production; among the most recurrent questions is the concern with the policies on distance learning and on scale certification; the contributions to subsidize the implementation and/or reformulation of proposals of continued formation of teachers are significant.

Keywords: continued formation of teachers; distance learning; reflexive perspective.

\section{Introdução}

As rápidas transformações das descobertas científicas em inovações tecnológicas provocam repercussões de caráter global no mundo contemporâneo (Dreifuss, 1996). Tais transformações afetam as mais variadas esferas da sociedade, traduzindo-se em mudanças econômicas, sociais, políticas, culturais, alterando, também, os comportamentos da vida cotidiana. Neste cenário contemporâneo, surge a demanda pela formação continuada de professores, visualizada em uma perspectiva de formação ao longo da vida, ou seja, como movimento de transformação e aquisição de saberes para enfrentar os novos tempos, capaz de conduzir à renovação de práticas pedagógicas (Belloni, 1999).

Em face dessa demanda, a Educação a Distância ${ }^{1}$ (EaD), na medida em que pôde contar com o apoio das tecnologias de informação e comunicação

\footnotetext{
${ }^{1}$ Embora Belloni (2002, p.156) afirme não haver consenso sobre a conceituação de EaD, propõe que a definição desta modalidade de ensino deve considerar as seguintes características: "a descontinuidade espacial entre professor e aluno, a comunicação diferida (separação no tempo) e a mediação tecnológica, característica fundamental dos materiais pedagógicos e da interação entre o aluno e a instituição".
} 
(TICs) para potencializar o processo ensino e aprendizagem, foi (re)vista enquanto alternativa capaz de contribuir para ampliar o acesso de professores a cursos de formação continuada. A pertinência da EaD em tal formação é defendida por diversos autores, entre eles E. G. Oliveira (2003b, p. 9), que destaca duas razões básicas para o seu aproveitamento.

\begin{abstract}
Por um lado, visa atenuar as dificuldades que os formandos enfrentam para participar de programas de formação em decorrência da extensão territorial e da densidade populacional do país e, por outro lado, atende o direito de professores e alunos ao acesso e domínio dos recursos tecnológicos que marcam o mundo contemporâneo, oferecendo possibilidades e impondo novas exigências à formação do cidadão.
\end{abstract}

A EaD desempenha papel relevante na formação continuada, uma vez que se fundamenta na aprendizagem autônoma (Peters, 2001), podendo ser integrada a ambientes de trabalho e, conseqüentemente, às experiências pessoais e profissionais dos professores. Por si só, no entanto, não resolverá os problemas educacionais brasileiros, pois, como afirma Belloni (1999), não se pode prescindir de uma postura crítico-reflexiva quando se busca a construção de projetos de formação continuada a distância e o desenvolvimento de políticas públicas para o setor. Essas críticas são corroboradas por dados contidos no documento "Estatísticas dos Professores no Brasil" (2003, p. 39), os quais revelam que a participação de professores em cursos de formação continuada "pouco afeta o desempenho dos alunos, o que indica a necessidade de ampliar as pesquisas nessa área e, eventualmente, reorganizar esses cursos, redefinindo seus objetivos e métodos".

Considerando que nos últimos anos tem havido uma disseminação da EaD como alternativa para formar professores, julgamos relevante aprofundar este tema. A expansão dessa modalidade educacional também encontra apoio na política que o Ministério da Educação, através da sua Secretaria de Educação a Distância (Seed), vem realizando, seja por meio de projetos, como Proformação, ProInfo, TV Escola, Rádio Escola e o Programa de Apoio à Pesquisa em EaD (Paped), ou do aumento da oferta de cursos de graduação a distância na área da educação, os quais, segundo dados do Censo do Ensino Superior, ${ }^{2}$ em 2004, já alcançavam um total de 107 cursos, sendo 67 (63\%) na área da educação, distribuídos da seguinte forma: 22 de Normal Superior, 16 de Pedagogia, 10 de Formação de Professores das Séries Iniciais do Ensino Fundamental e 19 de Formação de Professores de Disciplinas Específicas.

Perrenoud (1998, p. 206) afirma que "a formação contínua dos professores encontra-se em vias de institucionalização, mas está ainda à procura de seu lugar". Por concordarmos com este autor, acreditamos que os resultados de nossa pesquisa podem subsidiar formuladores de projetos de formação continuada a distância de professores.

\footnotetext{
${ }^{2}$ Dados coletados no site do Instituto Nacional de Estudos e Pesquisas Educacionais Anísio Teixeira (Inep): http://www.inep.gov.br/superior/censosuperior/sinopse/ default.asp, acessado em 20 de dezembro de 2005.
}

\section{Objetivos do estudo e procedimentos metodológicos}

O objetivo geral da pesquisa foi investigar como se apresenta, na produção acadêmica, a formação continuada a distância de professores; dele 
derivamos os seguintes objetivos específicos: a) analisar artigos/trabalhos que abordam a formação continuada de professores na modalidade EaD, identificando os focos de estudo que neles sobressaem; b) identificar nestes focos as questões recorrentes; e c) dimensionar a importância desses artigos/trabalhos enquanto subsídios para a elaboração de propostas de formação continuada de docentes via EaD.

O estudo define-se como documental, uma vez que exigiu levantamento de documentos (artigos e trabalhos), identificação e análise de características específicas, sendo privilegiada a abordagem qualitativa dos dados coletados.

O levantamento incidiu sobre os artigos e trabalhos publicados nos últimos cinco anos em periódicos nacionais, com circulação nacional e internacional, classificados pela Coordenação de Aperfeiçoamento de Pessoal de Nível Superior (Capes) na categoria indicativa de qualidade A, de acordo com os critérios Qualis. ${ }^{3}$ Foram considerados também os trabalhos que tratam deste tema apresentados nas Reuniões Nacionais da Associação Nacional de Pós-Graduação e Pesquisa em Educação (ANPEd) e na Revista Brasileira de Tecnologia Educacional; esta, embora não se inclua na categoria acima, possui significativa relevância, por ter sido pioneira na socialização de trabalhos sobre a EaD.

Ao todo foram analisados 15 periódicos, a saber: Cadernos de Pesquisa; Educação e Pesquisa; Educação e Sociedade; Revista Brasileira de Educação; Educar em Revista; Revista Brasileira de Estudos Pedagógicos; Revista Tecnologia Educacional; Educação e Realidade; Avaliação; Caderno Brasileiro de Ensino de Física; Cadernos de Educação; Educação PUC-RS; Ensaio - Avaliação e Políticas Públicas em Educação; Perspectiva; Pro-posições. Destes periódicos, apenas os sete primeiros publicaram artigos sobre o tema em tela. Os trabalhos apresentados nos Encontros Nacionais da ANPEd que integraram o levantamento foram obtidos no banco de dados disponibilizado na Internet por essa organização, o que facilitou a coleta de informações.

O levantamento exigiu uma análise inicial de todos os periódicos selecionados, publicados no período demarcado (2000-2004), os quais foram por nós situados como documentos da área educacional, uma vez que expressam a produção acadêmica publicada no País. Por meio do critério de palavras-chave (formação de professores, formação continuada, educação a distância), identificamos os artigos/trabalhos que passaram a constar do corpus da pesquisa. Quando o critério das palavras-chave se mostrou insuficiente para esta seleção, analisamos as referências bibliográficas apresentadas no final dos artigos, com o objetivo de determinar se havia obras que tratassem do tema. Em seguida, realizamos a leitura do resumo. Pairando dúvida quanto à inclusão do material, era feita uma leitura de todo o documento com vista à sua classificação.

Uma vez organizado o corpus, passamos à análise de seu conteúdo e, para tanto, nos apoiamos em Bardin (1992). Uma das funções básicas da análise de conteúdo é a inferência, o que exigiu compreender o discurso dos artigos (analisar as falas dos autores), identificando-se temas, idéias,

\footnotetext{
${ }^{3}$ Qualis (2003, p. 1) "é o processo de classificação dos veículos utilizados pelos programas de pós-graduação para a divulgação da produção intelectual de seus docentes e alunos. Tal processo foi concebido pela Capes para atender às necessidades específicas do sistema de avaliação e baseia-se nas informações fornecidas pelos Programas mediante a coleta de dados. Esta classificação é feita ou coordenada pelo representante de cada área e passa por processo anual de atualização. Os veículos de divulgação citados pelos programas de pós-graduação são enquadradas em categorias indicativas da qualidade (A, B, ou C) e do âmbito de circulação dos mesmos - local, nacional ou internacional. As combinações dessas categorias compõem nove alternativas indicativas da importância do veículo utilizado e, por inferência, do próprio trabalho divulgado. No entanto, não se pretende com essa classificação, que é específica para um processo de avaliação de área, definir qualidade de periódicos de forma absoluta".
} 
propostas, valores, posições, percepções, de tal modo que o resultado obtido pudesse ser organizado em categorias. ${ }^{4}$ Podemos, pois, dizer que este estudo concretiza uma análise documental, a qual, de acordo com Lüdke e André (1986), constitui um método de coleta de dados pertinente à abordagem qualitativa, por permitir identificar informações factuais nos documentos segundo as questões de interesse.

Esta análise documental demandou a leitura de todos os artigos/trabalhos que integraram o corpus da pesquisa. Com base em Bardin (1992), a leitura obedeceu às seguintes etapas e procedimentos: 1) pré-análise: tratou-se de uma leitura mais rápida, na qual buscamos verificar se o conteúdo de cada artigo/trabalho estava realmente relacionado com o nosso problema de estudo. A preocupação era, pois, determinar a representatividade de cada documento e ter uma visão geral do conjunto dos documentos; 2) leitura exploratória: configurada como uma leitura minuciosa, permitiu-nos organizar as informações em núcleos de compreensão (focos); 3) leitura interpretativa: nesta etapa, entrelaçamos os conteúdos dos diferentes artigos/trabalhos, determinando temas e subtemas comuns e questões recorrentes que emergiam nos textos; 4) leitura conclusiva: por seu intermédio pudemos identificar os subsídios encontrados nos focos dirigidos à elaboração de proposta de formação continuada de docentes via EaD.

Cabe registrar que, para dimensionar a importância desses artigos como subsídios à elaboração de propostas de formação continuada de docentes via EaD, tomamos por base o seguinte critério: presença de sugestões e alternativas evidenciando a preocupação de contribuir para a transformação da prática (Alves-Mazzotti, Gewandsznajder, 2000).

\section{Formação continuada a distância de professores na perspectiva reflexiva}

A perspectiva de formação continuada como processo permanente de reflexão sobre a experiência prática não é nova; nos anos 60, Furter (1992) e Trigueiro (1969) já abordavam essas questões ressaltando a importância da tomada de consciência e da intervenção do homem no seu próprio processo de aprendizagem.

Furter (1992, p. 137) considerou a educação contínua "uma necessidade imposta pela vida, devido ao seu próprio processo ininterrupto de mudanças". Para ele, a educação permanente estaria relacionada com a visão de homem inacabado, intrínseca à própria vida, atendendo à necessidade humana de aperfeiçoamento nas dimensões individual, social e profissional, num processo contínuo de formar e re-formar. Trigueiro (1969) defendeu a educação permanente como forma de atender à crescente demanda por uma nova formação, não limitada à configuração tradicional, na qual a escola se constitui a única fonte de conhecimento. Sua concepção de formação baseia-se na capacidade de aprender pela própria experiência, com ênfase na importância do fazer, da criatividade e do compromisso. Portanto, para esses dois autores, inseridos na realidade educacional dos anos sessenta, já 
estava clara a relevância da formação continuada como elemento indissociável da natureza humana e social e possibilidade de ultrapassar os limites da educação tradicional.

Nos anos setenta e oitenta, a idéia de formação continuada se consolidou, vinculando-se à perspectiva de treinamento. Cursos para "capacitar professores" se tornaram constantes, oferecendo modelos, sugestões, metodologias, "receitas" que poderiam promover mais facilmente a aprendizagem dos alunos. Carvalho e Simões (1999), ao pesquisarem a questão da formação continuada em artigos publicados na década de noventa, verificaram que havia um consenso entre os autores no sentido de recusar o significado de treinamento que usualmente lhe era atribuído, o qual implicava estratégias verticais de formação. Para essas autoras, a tendência reflexiva passou a predominar nos processos de formação continuada de professores, pelo menos em nível de discurso. Isto vem exigindo uma ressignificação da prática educativa, a qual deve ser percebida não apenas como um lugar de aplicação de teorias, mas de (re)elaboração constante dos saberes que os professores utilizam em suas atividades, bem como de confronto de experiências relacionadas com o contexto escolar.

Assumimos neste trabalho a perspectiva reflexiva de formação continuada de professores defendida por Nóvoa (1999), Schön (2000) e Zeichner e Diniz-Pereira (2005), a qual se contrapõe às iniciativas que insistem no modelo de complementação da formação inicial do professor, mediante o preenchimento de lacunas dos conhecimentos teóricos ou metodológicos e que, conseqüentemente, tendem ao fracasso, por não se apoiarem no contexto das práticas pedagógicas da escola. A visão reflexiva privilegia o confronto dialético entre teoria e prática, buscando levar o professor a estar sempre atento e crítico às variáveis presentes nas situações pedagógicas (Zeichner, Diniz-Pereira, 2005).

Segundo Libâneo (2004), as transformações nas práticas pedagógicas são conseqüência de um processo de conscientização sobre a própria prática, geralmente aliadas ao aprofundamento teórico e crítico da realidade. Afirma ele que a reflexividade deve estar associada à prática da pesquisa, como instrumento que proporciona pensar a prática, construir conhecimento, visando aprimoramento do trabalho docente. Por isso, espera que os processos de formação atendam às necessidades e desafios do cotidiano da escola, desenvolvendo conhecimentos, competências e valores que possibilitem a construção de novos saberes-fazer, propiciando flexibilidade mental e capacidade de resolver situações imprevistas.

Zeichner e Diniz-Pereira (2005) também defendem o desenvolvimento da pesquisa por educadores como forma mais adequada para a formação profissional. Segundo eles, a transformação nas práticas pedagógicas cotidianas depende do estabelecimento de uma aliança entre os professores das escolas e os acadêmicos das universidades. O estreitamento desses laços visa, não apenas, o desenvolvimento sistemático de pesquisas dirigidas às questões concretas do ensino-aprendizagem, mas, sobretudo, a construção de uma sociedade mais democrática, comprometida com a justiça social, econômica e política. Zeichner (1993) ressalta, ainda, que a reflexão precisa 
ser uma atitude coletiva, que redunde na construção de uma comunidade de aprendizagem capaz de fortalecer e sustentar o crescimento mútuo, provocando reais mudanças - institucionais e sociais.

Nóvoa (1999, p. 18) aprofunda esta questão alertando para o excesso de discursos baseados na retórica do "professor reflexivo", que encobrem práticas pedagógicas conservadoras caracterizadas pela rigidez curricular e direcionamento de livros e materiais didáticos produzidos por grandes empresas, de forma a atender o que chamou de "mercado de formação". Considera que muitas propostas se encontram distanciadas do sentido de reflexividade. Defende uma concepção de formação que valorize "a sistematização dos saberes próprios, a capacidade de transformar a experiência em conhecimento e a formalização de um saber profissional de referência". Neste sentido, apóia abordagens autobiográficas, baseadas em práticas de escrita pessoal ou coletiva e na atitude investigativa.

Entendemos que a perspectiva reflexiva oferece significativa contribuição à formação continuada, porque tem como eixo central a pesquisa sobre a ação docente. Por meio da pesquisa, o professor pode ultrapassar análises reducionistas, polarizadas ou limitadas à relação de causa-efeito, percebendo que a realidade é muito mais complexa do que se supõe, sendo, portanto, ingênuo querer compreendê-la pela via do senso comum ou pela ditadura do pensamento único (Bianchetti, 2002).

A consolidação da idéia de formação continuada de professores vem encontrando apoio na educação a distância, porém, conforme salienta Oliveira (2002), as abordagens mais comuns de formação continuada de professores a distância se baseiam em práticas pedagógicas instrucionistas, que privilegiam processos diretivos e rígidos de transmissão de conteúdos, valendo-se de pacotes fechados de informações predeterminadas, onde o aluno/professor individualmente cumpre as tarefas e as "devolve" ao professor/formador, evidenciando ênfase na memorização de conteúdos descontextualizados e no atendimento à massa. A autora admite, também, que os projetos de formação continuada de professores em EaD caminham para uma perspectiva inovadora, a qual assume uma concepção curricular mais flexível, não linear, baseada na pesquisa e no diálogo, com ênfase na mediação do professor/formador. Considera Oliveira (2002, p. 96) que "a formação continuada em serviço do professor encontra na EaD, apoiada pelas TICs, um instrumento para sua concretização", desde que atenda aos seguintes critérios: a) valorização do aluno/professor como sujeito crítico e não apenas como receptor/reprodutor do conhecimento imposto pelos especialistas; b) respeito à dimensão vivencial do tempo de cada sujeito aprendente, que se contrapõe à dimensão cronológica imposta a todos; c) respeito ao processo de construção de conhecimento do aluno/professor, não sobrepondo a intencionalidade pedagógica do professor/formador; d) integração à prática profissional, numa perspectiva reflexiva, concretizada por meio do trabalho com projetos; e) favorecimento da construção colaborativa e solidária de conhecimento.

Embora o uso das TICs na EaD possa oferecer maior variedade de informações aos estudantes, sua ênfase deve estar no desenvolvimento da 
autonomia. Para isto, Belloni (1999) recomenda a reorganização do processo de ensino-aprendizagem de modo a desenvolver as capacidades de autoaprendizagem por meio de metodologias que privilegiem a pesquisa e a interação social. Tal reorganização, no entanto, precisa considerar o alerta de Litwin (2001); para esta autora, o emprego das TICs na EaD como ferramentas que facilitam o acesso à informação não garante a construção do conhecimento. As tecnologias de comunicação devem privilegiar o uso da linguagem com a finalidade de pensar conjuntamente, propiciando o processo de construção coletiva do conhecimento. Assim, a mediação pedagógica torna-se um ponto essencial na EaD, exigindo do professor novas competências para mediar, orientar e desafiar o aluno, além de compreender criticamente as TICs, com vista a construir novas alternativas de acompanhamento e apoio ao aluno. As dificuldades em relação à mediação pedagógica têm gerado críticas, muitas delas destacando a forma simplória como a aula convencional é transposta para a modalidade a distância, desembocando em transcrições de livros e apostilas nos meios tecnológicos. Esta prática (re)produz o ensino conteudista e a didática tradicional.

Assumimos aqui que a EaD, como estratégia de formação de professores, exige novas posturas pedagógicas e metodológicas, o que significa pensar em "uma nova relação entre ensino, pesquisa, aprendizagem e avaliação processual" (Soares, 2000, p. 234). O processo de formação precisa preparar o profissional para atender às demandas da prática, levando em consideração as características situacionais ligadas à incerteza, à singularidade e aos conflitos de valores que se encontram presentes no cotidiano escolar. Para atuar nesse contexto, é preciso construir competências profissionais para o reconhecimento, julgamento e desempenho habilidoso. Assim, o conhecimento profissional não se limita à aplicação de determinados recursos ou instrumentos na solução de problemas, mas envolve, principalmente, a capacidade de criar, improvisar, testar estratégias para enfrentar as novas demandas educacionais (Schön, 2000).

\section{Resultados do estudo}

A partir do levantamento realizado nos periódicos selecionados e nos trabalhos apresentados na ANPEd no período de 2000-2004, selecionamos 37 artigos/trabalhos ${ }^{5}$ que abordavam o tema em tela. A princípio, esse número nos pareceu pequeno, pois é notória a existência de um grande volume de artigos/trabalhos sobre formação de professores. No entanto, com a leitura e análise da produção, constatamos a riqueza dos artigos/ trabalhos pela diversidade de temas e problemas abordados em torno da formação continuada de professores a distância.

Os artigos/trabalhos foram classificados de acordo com o tipo de abordagem, a saber: a) Resultados de Pesquisa (40\%) - trabalhos derivados de pesquisa acadêmica; b) Relatos de Experiência (19\%) - tinham como foco o registro de vivências educacionais; c) Comunicações Baseadas em Literatura (27\%) - estudos que envolviam, exclusivamente, revisão bibliográfica; e

\footnotetext{
As referências bibliográficas do artigos/trabalhos que compõem o corpus da pesquisa encontram-se no Apêndice.
} 
d) Análises de Pesquisas/Documentos (14\%) - tomaram como objeto de estudo pesquisas e/ou documentos anteriormente desenvolvidos.

Esses dados evidenciam que os periódicos pesquisados na seleção de seus artigos/trabalhos têm dado preferência a Resultados de Pesquisa (40\%) e Comunicações Baseadas em Literatura (27\%). É válido, pois, assinalar a importância que a pesquisa toma no contexto dessas publicações.

\subsection{Focos de estudo e questões recorrentes encontrados nos artigos/trabalhos pesquisados}

A diversidade de temas encontrados no material pesquisado demandou sua organização em núcleos de compreensão denominados focos, a saber: a) Políticas Públicas (32\%); b) Ambiente Virtual de Aprendizagem (22\%); c) Profissionalização Docente (19\%); d) Descrição e Avaliação de Projetos (19\%); e e) Práticas Pedagógicas (8\%).

Para oferecer a dimensão substantiva desse material, apresentamos uma síntese do conteúdo relativo a cada foco, destacando as questões recorrentes encontradas.

\subsubsection{Foco Políticas Públicas}

A análise das políticas públicas foi objeto de estudo de 12 artigos/ trabalhos. Destes, cinco preocuparam-se com o discurso tecnocrático e hegemônico do poder (Barreto, 2004, 2003, 2000; Belloni, 2002; Pretti, 2001); cinco analisaram programas desenvolvidos pelo MEC (Freitas, 2003; Silva Júnior, 2003; Gonçalves, 2002; Pretto, 2002; Pereira, 2002); um discutiu a apropriação crítica das TICs como instrumento de desenvolvimento social (Demo, 2000); e outro analisou a regulamentação, situando a EaD como espaço de formação de professores (Lobo Neto, 2001).

Os autores criticam a postura política adotada pelo governo federal alinhada a recomendações oriundas das organizações internacionais de financiamento, em especial do Banco Mundial, fundamentadas na concepção neoliberal, dirigidas especificamente para países em desenvolvimento (Barreto, 2004, 2003, 2000; Freitas, 2003; Pretto, 2002; Silva Júnior, 2003). Segundo Barreto (2003, p. 276), "os discursos de ordem econômica veiculam um modelo de substituição tecnológica, fundado na racionalidade instrumental e ancorado nas matérias de ensino".

Esta visão é compartilhada por Pretto (2002), quando afirma que as orientações do Banco Mundial privilegiam a formação econômica e rápida, o que redunda no modelo de formação a distância e em serviço. Segundo Pretto (2002) e Barreto (2000), essa proposição baseia-se no resultado de pesquisas internas do referido Banco, nas quais se constata que o desempenho dos alunos está intimamente relacionado com os materiais pedagógicos utilizados (pacotes instrumentais) e não com a formação do professor. 
Os autores alertam que o uso das TIC e as estratégias de formação de professores a distância estão a serviço de programas de certificação em larga escala, provocando o aligeiramento dos processos, devido à preocupação de atender à obrigatoriedade da formação de professores (Barreto, 2003; Pretti, 2001; Pretto, 2002; Freitas, 2003). Isto acaba provocando o esvaziamento e a precarização da profissão docente (Barreto, 2004, 2000). O trabalho do professor fica, então, restrito à escolha dos materiais didáticos e ao controle do tempo das aulas, em detrimento das mediações pedagógicas promovidas a partir da apropriação crítica das TICs na educação.

Demo (2000) também ressalta a importância da apropriação crítica das tecnologias nos processos de formação inicial e permanente dos professores, enquanto sujeitos que desempenham papel estratégico no desenvolvimento da sociedade e da cidadania. Ele defende a escola pública básica com inserção da tecnologia, para possibilitar o acesso da população marginalizada ao conhecimento e à tecnologia, visando, em última instância, integração ao mercado e desenvolvimento da cidadania.

Segundo Freitas (2003, p. 1107), "a política educacional vigente secundariza este aspecto da qualificação profissional, preferindo atuar na capacitação em serviço, privilegiando os aspectos técnicos e metodológicos do trabalho".

A preocupação com a regulamentação da EaD está presente no artigo de Lobo Neto (2001), que reconhece a intenção de formalizar esta modalidade, de modo a garantir a qualidade educacional. Alerta para algumas exigências presentes nas normas relacionadas com antigos preconceitos, como a determinação de avaliações finais presenciais que estão a serviço da manutenção do controle do processo de aprendizagem.

Analisando o alto investimento da inserção de tecnologias nas escolas (computadores, kit tecnológico com televisão, vídeo e antena parabólica e conexão à Internet), os autores destacam o novo filão do mercado educacional, promissor do ponto de vista econômico (Belloni, 2002; Pretto, 2002; Silva Júnior, 2003). Segundo Pretto (2002, p. 125), "enquanto o centro das políticas públicas não for a escola e os professores, não teremos mudanças substanciais, como teimam em insistir nossos governantes ao longo dos últimos anos".

Outro aspecto abordado refere-se ao processo de gestão da escola, de fora e de cima, ou seja, a verticalização do sistema e, conseqüentemente, sua homogeneização, por meio da disponibilidade de materiais em banco de dados e programas a distância para serem consumidos pelas escolas (Barreto, 2003, 2000; Pretto, 2002).

Esta visão também é corroborada por Silva Júnior (2003) ao analisar os programas da Secretaria de Educação a Distância (Seed), os quais, para ele, ainda se organizam de forma centralizada. O Estado é responsável pela formulação dos projetos e pela avaliação, evidenciando o viés regulatório presente nas atuais políticas (Freitas, 2003), cabendo aos professores e à escola o papel de meros executores. Esta concepção estaria orientada pela racionalidade mercantil, em detrimento da educação como prática social (Silva Júnior, 2003). 
Nas análises dos programas oficiais, os autores procuraram identificar as implicações das políticas públicas nos processos de qualificação docente (Pereira, 2002). Eles discutem o surgimento dos programas de formação a distância de professores como estratégia para atender às determinações legais de certificação massiva. Já Gonçalves (2002) apóia uma ação ampliada de formação de professores, visando atender a um maior número de profissionais de forma a flexibilizar a metodologia e reduzir custos. Salienta a importância das políticas públicas no setor que buscam inserir as tecnologias no cenário educacional. Destaca o convênio entre universidades, no caso, das Universidades Estaduais da Bahia com a Universidade Federal de Santa Catarina, objetivando formação de professores e a implementação de núcleos de EaD.

Pretto (2002) defende um maior envolvimento das universidades públicas nestes programas oficiais, exalta as propostas da Universidade Virtual Pública do Brasil (Unirede) e da Universidade Virtual do Centro-Oeste (UnivirCO), que seguem o modelo de consórcio.

Numa visão geral, as contradições entre o discurso tecnocrático das políticas e as realidades dos sistemas de ensino se refletem nos problemas enfrentados pelos professores no processo de formação continuada a distância. Esses problemas referem-se à falta de preparação para o auto-estudo, à baixa qualidade técnica na recepção dos materiais ou programas, à falta de manutenção dos equipamentos, à pouca motivação para a aprendizagem e às dificuldades em conciliar o tempo de estudo com a jornada de trabalho (Belloni, 2002).

\subsubsection{Foco Ambiente Virtual de Aprendizagem}

O estudo dos ambientes virtuais de aprendizagem (AVA) esteve presente em oito artigos/trabalhos. Deste conjunto, três discutiram suas características e potencialidades (Almeida, 2003; Leite, Teixeira, 2001; Paiva, Maciel, 2000); dois preocuparam-se com as interações digitais (Bruno, 2002; Oliveira, 2004); outros dois descreveram experiências em capacitação presencial e a distância (Franco, Cordeiro, Castilho, 2003; Guerra, 2001), e um abordou a importância da pesquisa e da autoria nesses ambientes (Belintane, 2002).

Almeida (2003, p. 331) apresentou um conceito de ambientes digitais de aprendizagem:

[...] sistemas computacionais disponíveis na Internet, destinados ao suporte de atividades mediadas pelas tecnologias de informação e comunicação. Permitem integrar múltiplas mídias, linguagens e recursos, apresentar informações de maneira organizada, desenvolver interações entre pessoas e objetos de conhecimento, elaborar e socializar produções tendo em vista atingir determinados objetivos. As atividades se desenvolvem no tempo, ritmo de trabalho e espaço em que cada participante se localiza, de acordo com uma intencionalidade explícita e um planejamento prévio denominado design educacional (Campos, Rocha, 1998; Paas, 2002), o qual constitui a espinha dorsal das atividades a realizar, sendo revisto e reelaborado continuamente no andamento da atividade. 
Os autores (re)afirmam que a utilização das TICs não determina inovações metodológicas no campo educacional, mas agrega novas possibilidades de aprendizagem. Evidenciam preocupação com a 'transposição mecânica' dos conteúdos do ensino presencial para os meios digitais (Almeida, 2003; Belintane, 2002), destacando que são necessárias novas habilidades de planejamento, desenvolvimento de estratégias e avaliação de ensino, assim como domínio do meio tecnológico (Leite, Teixeira, 2001).

$\mathrm{O}$ uso de ambientes digitais e interativos de aprendizagem favorece a produção do conhecimento individual e/ou coletivo em processos colaborativos (Almeida, 2003; Guerra, 2001). Demanda, também, uma concepção de produção do conhecimento em rede, fundada na atitude de investigação e crítica à prática pedagógica, por meio da metodologia de pesquisa situada como requisito do currículo (Paiva, Maciel, 2000; Belintane, 2002). Para que isto ocorra, Almeida (2003) considera indispensável que esses ambientes propiciem aprendizagem significativa e motivação para aprender, assim como disponibilizem informações e potencializem a interiorização dos conceitos construídos.

A apresentação das informações em hipertextos rompe as seqüências estáticas e lineares, levando o aluno a assumir um papel ativo na construção da aprendizagem, em consonância com seus interesses e necessidades (Almeida, 2003; Guerra, 2001). A linguagem hipertextual reconfigura os papéis do emissor e do receptor, que passam a basearem-se na multidirecionalidade, possibilitando a co-criação de conhecimentos e novas soluções para os problemas (Paiva, Maciel, 2000).

Alguns estudos salientam a necessidade de convergência entre diferentes mídias, linguagens e metodologias, com vista a se promover a interação (Almeida, 2003; Paiva, Maciel, 2000; Belintane, 2002). Outros defendem a presença da interação digital em ambientes de aprendizagem virtual, em uma perspectiva freireana de dialogia, o que pressupõe a constituição mútua dos sujeitos: formandos e formadores. Esta interação digital deve estar comprometida com a reflexão crítica do professor e, conseqüentemente, relacionada com as experiências do cotidiano escolar (Oliveira, 2004; Bruno, 2002). Esses dois autores concordam quanto à importância do estabelecimento de vínculos afetivos, destacando o papel do mediador tanto nas intervenções conceituais e reflexivas quanto nas afetivas.

Bruno (2002), preocupado com as dificuldades na inter-relação professor-aluno, propõe a reflexão sobre a linguagem utilizada nos ambientes de aprendizagem, em especial, a linguagem emocional. Defende, assim como Freire, que a emoção está relacionada com o processo de conscientização, podendo contribuir no desenvolvimento de profissionais crítico-reflexivos.

A nova grupalização oportunizada pelas salas virtuais, fóruns de discussão, intercâmbios de trabalhos, seminários online, possibilita que todas as mensagens sejam partilhadas, adquirindo a característica de "transparência", o que amplia as perspectivas de democratização do saber, ao mesmo tempo que desenvolve um novo modo de socialização (Paiva, Maciel, 2000, p. 12). 
Na perspectiva de democratização dos conhecimentos, Paiva e Maciel (2000) discutem a interiorização da ação da universidade pública como estratégia para o desenvolvimento social. Preocupam-se com a aproximação das universidades em relação ao cotidiano escolar, visando o atendimento às questões regionais (Belintane, 2002; Guerra, 2001). Belintane (2002) valoriza a co-autoria, expressa pela parceria universidade-escola, como possibilidade de emergência de respostas singulares e criativas para as questões relativas ao contexto escolar.

Franco, Cordeiro e Castilho (2003) descrevem dois tipos de formação (presencial e a distância) oferecidos aos professores universitários da Unicamp, visando à apropriação de ambientes virtuais de aprendizagem, no caso o TelEduc. Destacam vantagens no ensino a distância, a saber: estímulo à aprendizagem autônoma, à flexibilidade de tempo para leitura e discussão dos textos e à vivência em um curso a distância. Como desvantagem situam a necessidade de se dedicar maior tempo aos estudos e aos problemas técnicos a serem enfrentados. Já no ensino presencial as vantagens referem-se ao tempo concentrado para os estudos e a possibilidade de exploração técnica dos recursos disponibilizados no ambiente; como desvantagem sobressai a falta de tempo para as leituras e discussões necessárias.

Guerra (2001) analisa as possibilidades dessas duas modalidades de ensino, propondo a sua complementaridade. Analisa o projeto EducAdo, desenvolvido em encontros presenciais com uso das TICs, que tem como objetivo básico a construção de projetos e páginas de Web para a inserção de questões ambientais no currículo do ensino fundamental e médio. Após um período de capacitação, os professores retornam às suas escolas para desenvolverem os projetos cooperativamente, sendo acompanhados por meio de encontros virtuais assíncronos que buscam a reflexão crítica acerca dos problemas ambientais de suas regiões.

Em seu artigo, Leite e Teixeira (2001) apresentam algumas considerações sobre a construção de espaços virtuais de aprendizagem, incluindo: elaboração e planejamento por um grupo interdisciplinar; experiência anterior dos professores em ensino presencial e dos alunos em navegação na Internet; seleção das tecnologias utilizadas a serviço da concepção educacional; avaliação processual para exigir constante atualização dos alunos; e realização de convênios entre instituições para viabilizar economicamente os cursos.

\subsubsection{Foco Profissionalização Docente}

Embora a profissionalização docente seja uma questão que permeie a formação continuada de professores de forma geral, selecionamos sete artigos/trabalhos onde este tema é tratado de forma proeminente. Destes, dois discutem a formação do professor diante do novo paradigma educacional (Vilarinho, 2001; Oliveira, 2003a); três analisam a possibilidade de formação do professor reflexivo por meio da EaD (Toschi, 2000; Pedrosa, 2003; Lima, Grigoli, Barros, 2003) e dois analisam o papel do professor diante das TICs (Carneiro, 2003; Vilarinho, Barreto, 2004). 
Vilarinho (2001) e Oliveira (2003a) discutem as mudanças paradigmáticas e suas implicações na formação continuada de professores a distância. Ambas caracterizam o paradigma tradicional de ensino pela: reprodução do conhecimento (fragmentado, estático, linear e descontextualizado); visão de educador como detentor do conhecimento a ser transmitido ao educando passivo e submisso; aplicação de metodologias que valorizam a memorização e conduzem a respostas únicas e pré-determinadas. Concordam, também, que a superação desse paradigma dominante não ocorre de forma repentina e nem seus pressupostos desaparecem, mas seus modelos teóricos e metodológicos deixam de atender às demandas socioculturais.

Vilarinho (2001) aponta a concepção dialética dos educadores progressistas, a educação continuada e a educação a distância como anomalias (contradições) que podem contribuir para a ruptura do paradigma tradicional de ensino, uma vez que se baseiam em novas visões do processo de ensino-aprendizagem, entre elas a interatividade, a transitoriedade do conhecimento, a interdisciplinaridade e a autonomia. Essa autora destaca que a integração de diferentes mídias (rádio, correio, computador, telefone, fita cassete, CD-ROM e Internet) favorece e enriquece o processo ensino-aprendizagem, embora não possa ser considerada uma panacéia para todos os problemas na área educacional. Acredita na complementaridade das duas dimensões educacionais (educação continuada e educação a distância) e destaca a pós-graduação como o espaço mais adequado para o desenvolvimento desses projetos em face de algumas características, como: embasamento tecnológico; uso da pesquisa como caminho didático; experiência com a orientação acadêmica que estimula a autonomia dos alunos; visão integrada do conhecimento acadêmico; e incentivo à análise crítica e avaliação dos projetos.

Oliveira (2003a) adverte que o uso dos modernos recursos tecnológicos não garante uma prática pedagógica inovadora. Constata que muitos programas desenvolvidos em EaD ainda se fundamentam no paradigma tradicional, inspirado no modelo de racionalidade técnica e instrumental. Essa autora ressalta alguns aspectos da experiência do Curso de Especialização em Educação a Distância oferecido pela UnB condizentes com o paradigma emergente: uso das TICs na formação do sujeito como pessoa, promovendo a articulação dos conhecimentos; valorização do saber da experiência, por meio do registro de narrativas de vida; ênfase no trabalho coletivo como procedimento didático; preocupação dos orientadores acadêmicos com o próprio processo de autoformação.

Como as transformações sofridas pela sociedade afetam o papel do professor, Pedrosa (2003) ressalta a importância de uma efetiva política de formação inicial e contínua para os professores, afirma que o processo de profissionalização docente tem estreita relação com o seu processo de formação e defende a complementaridade e articulação entre formação inicial e continuada, numa unidade coerente e integrada. Segundo ela, a EaD pode servir de apoio às tarefas exercidas pelo professor ao incentivar o trabalho colaborativo e a troca de experiência. 
Levando em consideração que a EaD tem sido aplicada a diversas experiências de formação continuada de professores, as autoras, Toschi (2000) e Lima, Grigoli e Barros (2003) questionam o seu potencial para formar professores reflexivos. Afirmam que a formação reflexiva se contrapõe ao paradigma tradicional e à racionalidade técnica. Esse professor deve ser capaz de refletir criticamente sobre sua prática à luz da teoria, o que pressupõe a ruptura da dicotomia teoria-prática.

Toschi (2000) analisa a recepção do programa da TV Escola pelos professores e tece algumas críticas: não há interação com outros professores em formação, não é destacada a necessidade de momentos específicos, com previsão de tempo para estudo, por ser entendido como atividade de auto-aprendizagem. Assim, trata-se de proposta que pressupõe a maturidade do usuário e não oferece acompanhamento de um orientador ou mediador; não promove a interatividade com os materiais impressos e o mediador, o que reforça o caráter tecnológico do programa. A autora conclui que a TV Escola, por considerar os professores apenas como usuários de filmes, se descaracteriza enquanto EaD; em outras palavras, ao centrar-se na divulgação de material didático, a proposta esquece o profissional em formação. Visando à formação do professor reflexivo, o programa deveria oferecer atendimento pedagógico, suscitar debates, promover momentos coletivos de reflexão e formação de uma equipe escolar comprometida com a transformação da prática pedagógica.

Lima, Grigoli e Barros (2003) se ocuparam da formação pedagógica do professor universitário enquanto profissional reflexivo. Analisaram o curso "Aprendizagem Assistida pela Avaliação na Perspectiva do Ensino Superior", fundamentado na epistemologia da prática que adota a metodologia de situações-problema, casos e desafios. Para essas autoras, os participantes reconheceram, nas propostas de atividades e leituras oferecidas no curso, a "fidelidade ao propósito de promover uma reflexão sobre a prática avaliativa, na perspectiva de sua mudança". Este achado levou as autoras a concluírem que a "nova prática se aproxima do conceito de práxis pelas suas características de intencionalidade e consciência como se espera do professor reflexivo" (Lima, Grigoli, Barros, 2003, p. 13).

Em seus estudos, Carneiro (2003), Vilarinho e Barreto (2004) discutem a integração das tecnologias na formação de professores, na perspectiva de transformação do papel desse professor.

Carneiro (2003) analisa o curso "TV na Escola e os desafios de hoje", discutindo a formação do professor enquanto protagonista da integração da linguagem televisiva à sua prática pedagógica. O curso procurou incorporar a TV como cultura na escola, buscando o desenvolvimento de uma visão crítica sobre a mídia, e transformar o professor telespectador em mediador, no sentido de levá-lo a reconhecer o caráter lúdico e atrativo da TV para utilizá-la na dinamização do processo ensino-aprendizagem. Segundo essa autora (2003, p. 8), o papel do professor é mediar TV e estudantes:

[...] não para combater, recusar entretenimentos, mas provocar outras leituras de mundos, reconhecer ações e situações, explorar contextos, estruturar sentidos, avançar a compreensão, reconhecer que a TV medeia o mundo e nós. Analisar, criticar, expressar. 
A autora critica a visão de ensino direto ou aula pela TV, mais difundida no Brasil, que consiste em aulas gravadas, sem a mediação do professor, e critica também a subutilização da TV na educação, como instrumento apenas de transmissão de aulas, sem a exploração das potencialidades que a mídia pode oferecer. Como vantagem do curso investigado, destaca a formação em serviço que favorece a integração do que foi aprendido à prática, facilitando a transposição teórica às especificidades e singularidades dos contextos pedagógicos.

Vilarinho e Barreto (2004, p. 13) investigaram as possibilidades do uso da Internet no redimensionamento do papel do professor, destacando ser essencial a apropriação crítica deste recurso tecnológico por meio de uma abordagem ancorada na relação dialógica e na prática problematizadora. As autoras concluem que "o professor redimensionado é capaz de criar um ambiente de aprendizagem no qual os atores, pelo diálogo aberto e interativo, partindo de problemas contextualizados, buscam soluções de modo cooperativo".

De acordo com esses pesquisadores, a profissionalização docente está intensamente relacionada com o processo contínuo de formação, tendo em vista as mudanças paradigmáticas ocorridas na sociedade. A superação do paradigma tradicional de ensino demanda uma formação a distância baseada em novas concepções do processo educacional, entre elas: a) interdisciplinaridade: articulação dos conhecimentos visando melhor compreensão da complexidade dos problemas contemporâneos; b) contextualização: ênfase na formação em serviço, propiciando a reflexão crítica sobre a sua própria prática à luz das teorias; c) transitoriedade do conhecimento: adotando a metodologia de pesquisa, o aprender a aprender, por meio da prática problematizadora, ancorada na perspectiva de mudança; d) interatividade: promoção de trabalhos em grupo, debates e momentos coletivos de reflexão, visando à construção de uma equipe coesa e comprometida com a transformação da prática; e) autonomia: desenvolvimento de habilidades de auto-estudo e autoformação, mediante o acompanhamento do orientador de aprendizagem ou tutor.

\subsubsection{Foco Descrição e Avaliação de Projetos}

Dos sete artigos/trabalhos reunidos neste foco, três descrevem a implementação de cursos de formação continuada de professores a distância (Sá, 2001, 2003; Oliveira, Nogueira, 2002); um tece comparação entre as duas modalidades de capacitação: presencial e a distância (Duarte, 2004); dois abordam as representações de professores em relação a EaD (Couto, Lima, 2003; Lima, 2002); e outro reflete sobre a formação da identidade de aluno (Barrenechea, 2003).

Sá (2001, 2003) descreve a implementação do Curso de Graduação em Pedagogia - séries iniciais do ensino fundamental, na UFPR, oferecido para professores da rede pública e confessional do Paraná. Os princípios norteadores do curso foram: trabalho pedagógico considerando as especificidades da escola onde atua o professor; práxis educativa no sentido 
de movimento constante e dialético entre teoria e prática; pesquisa propiciadora do diálogo crítico com a realidade; e interdisciplinaridade com vista à compreensão da complexidade do fenômeno educativo. Esse projeto fundamentou-se na organização do trabalho docente, que apesar da divisão de tarefas deve preservar a coesão e a integração no processo educativo; na valorização do tutor, responsável pela mediação pedagógica, avaliação contínua, acompanhamento e motivação dos alunos; e na elaboração do material impresso, privilegiando a linguagem dialógica propiciadora do estudo individualizado.

Oliveira e Nogueira (2002) relatam a construção do Curso Pedagogia Licenciatura para os anos iniciais do ensino fundamental, oferecido pelo Centro Universitário de Educação a Distância no Rio de Janeiro (Cederj), projeto desenvolvido em parceria com a Universidade Estadual do Rio de Janeiro (Uerj) e Universidade Federal do Estado do Rio de Janeiro (Unirio). Esta proposta tem como objetivos: contribuir para a interiorização do ensino superior; aumentar as vagas no ensino gratuito e de qualidade; facilitar o acesso com apoio da flexibilização do tempo; e promover a formação continuada de professores do Estado. Seus princípios norteadores são: contextualização das ações pedagógicas; ênfase na interação e discussões coletivas; adoção da metodologia de pesquisa; acompanhamento tutorial presencial e a distância; articulação teoria e prática; formação integral, ética e emancipatória; avaliação contínua, visando ao aperfeiçoamento do programa.

Podemos constatar semelhanças nos princípios norteadores de ambos os cursos descritos, respectivamente, por Sá (2003) e Oliveira e Nogueira (2002), são eles: a) consideram o contexto de atuação do professor nas unidades escolares, suas especificidades socioculturais; b) baseiam-se na epistemologia da prática, na articulação indissociável entre teoria e prática; c) privilegiam a metodologia de pesquisa; d) promovem a construção coletiva do conhecimento por meio do diálogo e da interação entre os participantes; e) valorizam o papel do orientador de aprendizagem ou tutor, não apenas para tirar dúvidas dos alunos, mas para acompanhar o processo de aprendizagem como mediador e incentivador; f) assumem a avaliação como processo contínuo, visando conscientizar o aluno quanto às necessidades do seu próprio processo de aprendizagem e aperfeiçoamento do curso.

Em seu artigo, Duarte (2004) compara dois projetos de formação: o Projeto de Educação Continuada (PEC/SP) na modalidade presencial e o Programa de Capacitação de Professores (Procap/MG), que adota a modalidade mista (presencial e a distância). Independentemente da modalidade dos cursos em questão, a autora constata o fracasso de ambos por não provocarem mudanças na forma de atuação do professor em sala de aula; ressalta, no entanto, sua importância ao atingirem um grande número de professores e ao valorizarem o processo de capacitação dos professores. Como pontos positivos do PEC/SP, situa: tentativa de atender às especificidades das escolas; inserção do professor enquanto sujeito ativo e participativo do processo, promovendo a integração com universidades; valorização dos saberes dos professores; modelo baseado na ação-reflexão-ação. Já os aspectos negativos referem-se a: falta de incentivos para a capacitação dos 
professores; não adequação do projeto ao calendário escolar; e interferências da Secretaria de Educação no remanejamento das equipes docentes, impedindo a concretização do trabalho coletivo nas escolas. No Procap/MG, considera relevante o compromisso com a capacitação, adequando-se ao calendário escolar, e a criação de incentivos aos participantes. Os aspectos negativos encontrados foram: centralização das decisões, promovendo a padronização das capacitações, e inadequação às especificidades e necessidades das unidades escolares. A autora atribui os aspectos negativos à utilização da EaD.

A avaliação de projetos de formação a distância, segundo a ótica dos próprios professores participantes, foi objeto de estudo nos trabalhos de Couto e Lima (2003) e Lima (2002). Ambos investigaram as representações dos professores em relação a EaD.

Couto e Lima (2003) investigaram as percepções de professores no curso de extensão "TV na Escola e os desafios de hoje". Realizaram um levantamento das vantagens e desvantagens expressas no discurso de quatro professores, sujeitos da pesquisa, sobre o referido curso. Situaram como vantagens: flexibilidade e autonomia para administrar o tempo e local de estudo; e possibilidade de conciliar estudo e trabalho. Como desvantagem: estudar sozinho, sem a presença constante do professor e de outros colegas. As autoras ressaltaram a conscientização por parte dos professores quanto à importância do uso das tecnologias como facilitadoras do processo educacional. Os professores participantes da pesquisa salientaram o isolamento na construção do conhecimento como causa de desinteresse e desânimo para continuar os estudos. As autoras constataram também que a questão relativa ao processo de formação em serviço não esteve presente nos discursos dos professores, já que eles não tiveram oportunidade de estudar e assistir aos vídeos no próprio local de trabalho, reforçando a sensação de solidão.

Esta questão também foi levantada na pesquisa de Lima (2002), quando analisou o depoimento de professores participantes do projeto TV Escola em escolas públicas de São Paulo. Os professores apresentaram restrições aos projetos de formação continuada a distância, considerando que as situações de grupo em cursos presenciais proporcionam melhores condições para a aprendizagem. Assim, evidenciaram uma resistência à aprendizagem solitária.

O estudo de Barrenechea (2003) investiga a construção da autonomia e identidade do aluno que participa do Curso de Formação de Professores das Séries Iniciais do Ensino Fundamental, na modalidade a distância, oferecido pela UFPR. Discute situações que dificultam a construção da identidade do aluno em formação profissional. Tais situações relacionam-se com os procedimentos adotados pela biblioteca que impedem o empréstimo de livros; à restrição do direito ao voto no processo de eleição para reitor, vice-reitor e diretor do Departamento de Educação; e à ausência de um Centro Acadêmico que funcione como fórum de discussão de questões de interesse dos alunos a distância. Barrenechea (2003, p. 5) conclui que: 
[...] enquanto ele (aluno) não se constitui como sujeito coletivo na universidade, ele não consegue construir sua autonomia. Pois para se ter autonomia é preciso que haja um sujeito desta autonomia. Se ele (aluno) não é visto como sujeito participante nesta comunidade, ele não se percebe como sujeito integrante deste coletivo, para então buscar sua representação e legitimação. Este sujeito se baseia em uma identidade coletiva de aluno.

Articulando os estudos de Barrenechea (2003) aos de Couto e Lima (2003) e de Lima (2002), surge uma questão: a solidão enfrentada pelos alunos a distância, expressa nas falas que configuram um isolamento no processo de construção de conhecimento, não estaria relacionada com a dificuldade de constituir uma identidade coletiva de aluno, referenciada na dimensão de sujeito participante da comunidade de aprendizagem?

\subsubsection{Foco Práticas Pedagógicas}

Neste foco reunimos três artigos/trabalhos, a saber: Belloni (2003), Gatti (2003) e Souza e Oliveira (2003). Estes artigos/trabalhos possuem em comum a preocupação com o aproveitamento das TICs nas práticas pedagógicas dos professores que participaram de cursos de formação a distância.

Belloni (2003) discute a apropriação dos programas da TV Escola pelos professores. A autora propõe a dupla dimensão do uso pedagógico das TIC: como ferramenta pedagógica e como objeto de estudo, privilegiando o "processo de apropriação crítica e não de consumo instrumental e passivo" (Belloni, 2003, p. 289). Ela afirma que a proposta original da TV Escola se baseava na formação aberta, flexível e informal (sem avaliação e certificação) e no oferecimento de programação variada para livre escolha do professor das séries iniciais do ensino fundamental. Esta proposta, no entanto, foi sendo modificada à medida que o programa ampliava sua abrangência, destinando-se a docentes de qualquer nível de ensino e oferecendo material didático para uso em sala de aula. Tais transformações revelaram que os professores mais beneficiados com o programa são aqueles que menos necessitam, já que possuem condições de exercer o papel de estudante autônomo. Analisando o pouco aproveitamento da TV Escola, a autora aponta para questões relacionadas com a carreira do professor: falta de tempo, precária formação inicial, inexistência do hábito de auto-estudo, baixo nível salarial e pouca motivação para formação devido à ausência de incentivos. Segundo Belloni (2003, p. 297),

[...] as dificuldades da TV Escola explicam-se pela falta de projetos coletivos de formação continuada na maioria das escolas e pela ausência de uma política que inverta essa relação perversa de centralização e descentralização, por meio da qual as decisões pedagógicas são tomadas por tecnocratas no ministério e tarefas técnicas repetitivas são exigidas dos professores, fora de sua jornada de trabalho.

Gatti (2003) analisa as condições que provocam transformações no pensar e na prática pedagógica, resultantes de um programa de formação 
em serviço de professores a distância: o Proformação. Constata ser indispensável promover a integração do curso ao meio sociocultural e profissional, não se limitando apenas ao desenvolvimento cognitivo dos participantes. Destaca o envolvimento das diferentes esferas administrativas (federal, estadual, municipal e local) propiciadoras da construção de vínculos socioculturais entre o programa, os realizadores e os participantes. Acredita que o estabelecimento desses vínculos se concretiza pela atuação de tutores, residentes na mesma localidade, que ofereceram atendimento continuado e contextualizado aos participantes. Essa forte relação foi expressa pelo pequeno índice de evasão, constatado no programa, atribuído ao trabalho dos agentes educacionais próximos aos participantes. Ressalta o papel do tutor como mediador e criador de laços sociocognitivos, afetivos e motivacionais. Afirma que

[...] tudo isso reforça a idéia de que, para que mudanças em concepções e práticas educacionais de professores ocorram, é necessário que os programas que visam a inovações educacionais, aperfeiçoamentos, atualizações tenham um entrelaçamento concreto com a ambiência psicossocial em que esses profissionais trabalham e vivem (Gatti, 2003, p. 203).

Souza e Oliveira (2003) buscaram compreender as implicações do projeto Rádio pela Educação, em especial do programa "Para Ouvir e Aprender", na prática pedagógica de unidades escolares da Região Amazônica. Este programa, ao constituir-se como recurso pedagógico a ser utilizado durante as aulas nas primeiras séries do ensino fundamental, acabou se tornando uma oportunidade de formação continuada de professores. O projeto visa à produção de textos (cartas) a partir do debate de problemas pessoais ou coletivos da escola/região. As cartas são apresentadas nos programas, estimulando a participação de todos, inclusive da comunidade. Essa dinâmica provocou mudanças no tratamento pedagógico dos temas curriculares, passando a exigir um "processo de busca, construção e questionamento coletivo e síntese". Nas palavras dos próprios autores (Souza, Oliveira, 2003, p. 9),

[...] os professores têm sido desafiados a se desprenderem de práticas mais tradicionais e a investirem em práticas pedagógicas reflexivas, criadoras e com especial significado para suas próprias práticas e para o movimento educacional que estão instalando em suas classes, qualificando o debate e as discussões em sala de aula, o que materializa, mesmo que indiretamente, uma estratégia de formação continuada dos docentes.

Em complemento, apresentaram o descontentamento de alguns professores que percebiam os programas desconectados do fazer educativo; por isso, muitos desligavam o aparelho de rádio, deixando de aproveitar as propostas em suas aulas. Tal fato evidencia a necessidade de um acompanhamento pedagógico que promova a conscientização e utilização adequada deste recurso - o rádio - como "instrumento ágil de mobilização e ferramenta que proporciona o acesso à informação para todos os segmentos sociais" (Souza, Oliveira, 2003, p. 13). 
Dessas leituras, podemos destacar alguns aspectos determinantes na transformação da prática pedagógica: a) aproveitamento triplo das TIC, como ferramenta pedagógica, enriquecendo a prática na sala de aula, objeto de estudo e de formação do professor; b) interação dos realizadores de projetos e dos participantes, visando à descentralização das decisões pedagógicas e ao atendimento de necessidades concretas; c) relevância do papel do orientador de aprendizagem ou tutor como elemento facilitador no desenvolvimento de habilidades de auto-estudo e autonomia dos participantes e responsável pelo estabelecimento de um vínculo sociocultural e motivacional; d) valorização do profissional docente, a partir de incentivos para sua formação continuada.

\subsection{Propostas e sugestões para a formação continuada a distância de professores}

Para dimensionar a relevância dos artigos/trabalhos pesquisados em termos de oferecimento de subsídios para novas propostas de formação continuada a distância de professores, consolidamos as sugestões dirigidas à transformação da prática. Essas sugestões foram agrupadas segundo os focos de análise dos artigos/trabalhos anteriormente destacados.

\subsubsection{Foco Políticas Públicas}

Os artigos/trabalhos que analisam as políticas públicas tendem a oferecer propostas genéricas de reestruturação da prática pedagógica, entre as quais destacamos:

a) definição de uma política de formação e valorização do professor, atendendo à formação inicial e continuada, melhoria nas condições de trabalho, salário e carreira (Freitas, 2003);

b) fortalecimento de processos horizontais de formação, com maior envolvimento dos professores, gestores locais e regionais na elaboração e atualização de projetos e políticas de formação continuada de professores, ou seja, mudança no papel desses profissionais como autores e colaboradores no processo de formação e não apenas como consumidores de pacotes instrucionais homogêneos, elaborados por uma minoria de especialistas (Pretto, 2002; Belloni, 2002; Demo, 2000);

c) formação dos educadores priorizando o desenvolvimento de competências para o trabalho coletivo e para a gestão democrática e promovendo a participação ativa, baseada na visão interdisciplinar, nos princípios de solidariedade e no compromisso com a emancipação (Freitas, 2003);

d) elaboração de políticas centradas nas tecnologias, visando à democratização do acesso e à apropriação crítica que possibilite ao professor redimensionar as práticas de ensino (Barreto, 2003), por meio 
da reflexão crítica e discussões a partir das situações concretas e singulares enfrentadas no dia-a-dia (Barreto, 2004);

e) preocupação com uma formação geral sólida, fundamentada em valores éticos, que se contraponha ao aligeiramento do processo e de certificação em grande escala.

[...] não podemos simplesmente seguir as exigências do mundo do trabalho, as demandas do mercado por novas habilidades e competências a serem apreendidas para o exercício profissional. E a formação para a vida? E os nossos valores e nossa cultura? Temos que recuperar os vínculos entre educação, trabalho, produção, vida cotidiana de existência. Aí é que estão o educativo e o formativo. Eles acontecem, não importa se de maneira presencial ou a distância (Pretti, 2001, p. 37).

\subsubsection{Foco Ambientes Virtuais de Aprendizagem}

Neste foco, as propostas se concentram nas questões relativas à interatividade e importância do papel do mediador, assim como na formação de uma equipe interdisciplinar comprometida com a prática pedagógica. Entre elas se destacam:

a) a interatividade, potencializada nos ambientes virtuais de aprendizagem, deve estar a serviço da produção coletiva do conhecimento, favorecendo a participação ativa e a metacognição sobre os processos de aprendizagem (Paiva, Maciel, 2000);

b) a mediação pedagógica nos ambientes de aprendizagem deve ser permeada por uma linguagem emocional e afetiva, de modo a garantir a formação de um espaço harmônico, propiciador de construções e reflexões em níveis crescentes de complexidade (Bruno, 2002; Oliveira, 2004);

c) é fundamental a implementação de uma equipe multidisciplinar, na qual os mediadores estejam envolvidos em todas as etapas do processo educativo, de modo a se evitar a fragmentação do discurso entre a equipe que desenvolve os conteúdos e módulos e a equipe responsável pela interação com os alunos (Oliveira, 2004);

d) há necessidade de os formadores a distância participarem de processos de formação continuada com uso das TIC, para refletirem sobre o seu próprio processo de aprendizagem e as contribuições das tecnologias na prática pedagógica (Almeida, 2003);

e) a elaboração de material didático deve fundamentar-se em uma visão de matriz gerativa, que permita a co-autoria e promova a interação, ou seja, partir de uma estrutura genérica que vá possibilitando a criação de novos módulos, visando aos interesses e singularidades regionais (Belintane, 2002);

f) deve haver uma aproximação entre a pesquisa universitária e os projetos desenvolvidos nas redes escolares, de modo a intensificar o intercâmbio e estreitar as relações entre a produção do conhecimento e suas aplicações contextualizadas (Belintane, 2002); 
g) os cursos a distância devem ser desenvolvidos por equipe interdisciplinar, responsável pela elaboração de um plano instrucional detalhado, que possibilite a autonomia dos alunos; é fundamental incluir uma unidade introdutória para familiarizar o aluno com a tecnologia, que precisa ser coerente com as estratégias de ensino adotadas; os professores precisam ter experiência no ensino presencial, e os responsáveis pelo seu desenvolvimento devem acompanhá-lo pelo menos uma vez; a avaliação deve incluir exercícios e testes semanais, para os alunos manterem-se atualizados; as diversas atividades devem compor a nota final (Leite, Teixeira, 2001).

\subsubsection{Foco Profissionalização Docente}

Neste foco as sugestões para o aperfeiçoamento de práticas incidiram sobre pontos distintos, mas que se unem pela idéia de cultura institucional, considerando tanto o que a instituição pode oferecer quando se propõe formar professores a distância quanto o que estes atores trazem como contribuição, segundo as experiências profissionais já vivenciadas. Assim, foram encontradas as seguintes propostas:

a) o espaço privilegiado para a integração da educação continuada e a distância seria o ensino superior, devido ao suporte tecnológico (as instituições já estão conectadas) e metodológico (experiência com pesquisa e orientação acadêmica) (Vilarinho, 2001);

b) é importante a construção de uma cultura institucional que incentive a formação continuada de professores, buscando o desenvolvimento profissional e a implementação de um processo de acompanhamento que apóie as práticas inovadoras (Lima, Grigoli, Barros, 2003);

c) nos projetos de $\mathrm{EaD}$ as tecnologias precisam estar a serviço da construção do conhecimento por meio da realização de trabalhos colaborativos, baseados em pesquisa e resolução de problemas (Oliveira, 2003a);

d) os cursos a distância devem considerar a base cultural e socioeconômica, os interesses, as experiências e a familiaridade dos participantes com a tecnologia (Pedrosa, 2003);

e) as sugestões específicas ao projeto TV Escola: inclusão de um mediador para atuar junto aos professores, promovendo o debate de idéias e o planejamento de ações pedagógicas: planejamento de momentos específicos na jornada de trabalho do professor, visando à reflexão coletiva e à formação de uma equipe escolar comprometida com a transformação da prática pedagógica; reestruturação dos materiais e programas para promover maior interatividade entre os participantes (Toschi, 2000). 


\subsubsection{Foco Descrição e Análise de Projetos}

Devido às peculiaridades dos projetos analisados nestes artigos/trabalhos, apresentamos as propostas e/ou sugestões relacionadas com os cursos estudados.

a) Curso de Formação de Professores das Séries Iniciais do Ensino Fundamental da UFPR:

- necessidade de fortalecer o diálogo aberto na instituição, por meio de discussões e avaliações, de modo que a importância do curso seja reconhecida por toda a comunidade acadêmica (Barrenechea, 2003);

- estabelecimento de convênios entre a universidade e instituições da sociedade civil para garantir o funcionamento do curso, devido ao seu limitado financiamento (Sá, 2003);

b) Projeto TV Escola:

- discutir as necessidades de formação continuada da equipe e, em especial, as possibilidades e limitações da educação a distância (Lima, 2002);

c) Curso de Extensão "TV na Escola e os Desafios de Hoje"

- discutir conteúdos e enfoques novos por meio da problematização da prática e da experiência dos próprios professores participantes, refletindo criticamente sobre a presença da mídia na educação e na sociedade (Couto, Lima, 2003);

d) Projeto de Educação Continuada (PEC/SP) e Programa de Capacitação de Professores (Procap/MG):

- atender ao conjunto dos professores de uma escola para a formação de uma equipe de trabalho comprometida com a modificação das práticas; oferecimento de incentivos para motivar os professores a se envolverem em programas de capacitação; centralizar os projetos nos problemas cotidianos e vivências dos professores; construir instrumentos para avaliar a eficiência desses programas e orientar a tomada de decisões e os planejamentos políticos (Duarte, 2004).

\subsubsection{Foco Práticas Pedagógicas}

Nos artigos/trabalhos enquadrados neste foco, observamos que as sugestões referem-se às situações específicas ali consideradas.

a) Projeto Rádio pela Educação - Programa "Para Ouvir e Aprender": maior participação dos professores na escolha dos temas, textos, músicas e técnicas de trabalho a serem veiculadas nos programas, com vista ao aproveitamento de suas experiências; aperfeiçoamento do material com a elaboração de novos guias pedagógicos para orientação aos professores; melhorias na transmissão do programa e 
planejamento de um acompanhamento pedagógico dos docentes e das escolas participantes do projeto (Souza, Oliveira, 2003);

b) Projeto TV Escola: criação de uma estrutura técnica responsável por gravar e catalogar os programas; formação de uma equipe pedagógica para orientar os professores no planejamento e realização de atividades de aproveitamento do material, nas duas vertentes - para autoformação e uso didático com os alunos; estabelecimento de parcerias com as universidades, visando criar estratégias de uso coletivo a serem integradas aos grupos de estudos; inclusão de seu uso durante as formações iniciais e continuadas dos professores (Belloni, 2003);

c) Proformação: maior integração dos conteúdos abordados com as experiências pessoais e profissionais dos participantes do projeto, visando promover a contextualização e a aprendizagem significativa; e envolvimento das administrações educacionais locais na realização direta do programa, promovendo a constituição de vínculos socioculturais (Gatti, 2003).

\section{Conclusões}

A análise do conteúdo desses focos nos possibilitou traçar um paralelo entre as questões recorrentes que neles se inseriam e o embasamento teórico da pesquisa.

O foco Políticas Públicas foi o que se apresentou mais proeminente, não só por reunir maior número de artigos/trabalhos (12), mas, principalmente, por apresentar as críticas contundentes e instigantes; dentre elas, destacamos a preocupação com políticas de aligeiramento e certificação em escala, que se coaduna à concepção neoliberal. Esta concepção acaba favorecendo a visão de educação como negócio lucrativo e promissor e, como conseqüência, estimula a produção e distribuição de pacotes com "soluções" educacionais, reduzindo as potencialidades da EaD. As críticas encontradas nos artigos/trabalhos também estão presentes nos estudos de Zeichner (2005) e Nóvoa (1999). Elas alertam para o crescente "mercado de formação" e, embora possam empregar o discurso da formação de professores prático-reflexivos, veiculam propostas centralizadoras e distanciadas do contexto e dos problemas enfrentados na escola. Verificamos aqui que, na busca de alternativas para esse modelo e visando preservar (ou implementar) a qualidade educacional na EaD, há uma afinidade entre as idéias apresentadas nos artigos/trabalhos e as dos autores que compõem nossa abordagem teórica - todos propõem a necessidade de apropriação crítica das TICs, o estabelecimento de parcerias com universidades no desenvolvimento de pesquisas que abordem as questões concretas e as especificidades vividas nas escolas.

No foco Ambiente Virtual de Aprendizagem, os artigos/trabalhos estão preocupados com o processo de construção do conhecimento nos cursos de formação a distância, em face do grande volume de informações 
disponibilizadas pelas TICs. Em linhas gerais, indicam a necessidade de uma reestruturação ampla dos cursos que envolva desde a adoção de uma matriz curricular flexível e interdisciplinar à implementação de metodologias de pesquisa, estimulando a atitude de investigação, até o fortalecimento da interação digital, baseada em vínculos afetivos e motivacionais que possibilitem a construção coletiva do conhecimento. A importância da atitude coletiva é percebida por Zeichner (1993) e Oliveira (2002) como fundamental não só para construção do conhecimento, mas principalmente para provocar transformações nas práticas pedagógicas.

O foco Profissionalização Docente, entre outras questões, aborda as mudanças paradigmáticas e a formação do professor reflexivo, temas recorrentes nos discursos de diversos autores que integram nosso embasamento, como Libâneo (2004), Nóvoa (1999), Schön (2000) e Zeichner (1993). Da análise interpretativa dos conteúdos encontrados neste foco, concluímos que seus autores entendem as mudanças paradigmáticas como estímulo à busca de outras propostas de formação profissional, mais adequadas ao novo contexto social. Eles salientam a demanda de profissionais preparados para atuarem em situações singulares e incertas. Assim, a formação continuada de professores a distância deve estar comprometida com a transformação das práticas pedagógicas, baseando-se, sobretudo, em processos de reflexão, valorizando as experiências e os saberes dos professores.

Na Descrição e Avaliação de Projetos e Práticas Pedagógicas foi retomado o princípio básico da EaD: democratização do acesso à educação, com a discussão de suas possibilidades no sentido de facilitar a interiorização da universidade. A parceria universidade-escola também é defendida por Zeichner (2005). Os autores vinculados a este foco acreditam que a EaD pode propiciar o diálogo crítico com a realidade, na medida em que o aluno não precisa se ausentar de seu contexto, permitindo, ao mesmo tempo, que se fortaleça a construção de uma identidade coletiva e regional. Para que a abertura da universidade e as transformações nas práticas escolares ocorram, é importante ressaltar o papel da mediação pedagógica, responsável pelo acompanhamento da aprendizagem, avaliação e motivação dos alunos, numa perspectiva de contextualizar e atender às especificidades da escola. A importância da mediação pedagógica está presente no discurso de Litwun (2001) e constitui uma das questões mais recorrentes no foco das práticas pedagógicas, o que evidencia a complementaridade das idéias apresentadas em diferentes focos.

Nossa pesquisa, ao buscar as tendências do tema em tela, em um dado período (2000-2004), apontou a diversidade de preocupações e abordagens. Os artigos e trabalhos que constituíram o corpus do estudo não esgotam o pensamento educacional, que circula em nosso país, sobre formação continuada a distância de professores, mas certamente refletem as concepções de educadores reconhecidos nacionalmente. Esperamos que outros pesquisadores possam se valer dos achados aqui apresentados, ampliando e/ou reformulando nossa leitura. 


\section{Referências bibliográficas}

ALMEIDA, M. E. B. Educação a distância na internet: abordagens e contribuições dos ambiente digitais de aprendizagem. Educação e Pesquisa, São Paulo, v. 29, n. 2, p. 327-340, jul./dez. 2003

ALVES-MAZZOTI, A. J.; GEWANDSZNAJDER, F. O método nas ciências naturais e sociais: pesquisa quantitativa e qualitativa. São Paulo: Pioneira, 2000 .

BARDIN, L. Análise de conteúdo. Lisboa: Edições 70, 1992.

BARRENECHEA, C. A. A formação da identidade do aluno na educação a distância: reflexões para um debate. Educar, Curitiba, n. 21, p. 117-131, 2003.

BARRETO, R. G. Multimídias, organização do trabalho docente e políticas de formação de professores. Trabalho apresentado na $23^{\text {a }}$ Reunião Anual ANPEd, Sessão Especial, 2000.

. Tecnologia e educação: trabalho e formação docente. Educação G Sociedade, Campinas, v. 25, n. 89, p. 1181-1201, set/dez. 2004.

Tecnologias na formação de professores: o discurso do MEC. Educação e Pesquisa, São Paulo, v. 29, n. 2, p. 171-286, jul./dez. 2003.

BELINTANE, C. Por uma ambiência de formação contínua de professores. Cadernos de Pesquisa, São Paulo, n. 117, p. 177-193, nov. 2002.

BELLONI, M. L. A televisão como ferramenta pedagógica na formação de professores. Educação e Pesquisa, São Paulo, v. 29, n. 2, p. 287-301, jul./ dez. 2003

. Ensaio sobre a educação a distância no Brasil. Educação G Sociedade, Campinas, v. 23, n. 78, p. 117-142, abr. 2002.

1999.

Educação a distância. Campinas (SP): Autores Associados,

BIANCHETTI, L. Prefácio. In: MEKSENAS, P. Pesquisa social e ação pedagógica: conceitos, métodos e práticas. São Paulo: Loyola, 2002.

BRUNO, A. R. A linguagem emocional: tecendo a razão e a emoção nos cursos de formação em ambientes telemáticos. Trabalho apresentado na 25ª Reunião Anual ANPEd, GT 16 - Educação e Comunicação, 2002.

CARNEIRO, V. L. Q. Integração da TV na prática, na formação do professor: desejos, propostas, desconfianças, aprendizados. Trabalho 
apresentado na 26ª Reunião Anual ANPEd, GT 16 - Educação e Comunicação, 2003.

CARVALHO, J. M.; SIMÕES, R. H. S. O processo de formação continuada de professores: uma construção estratégico-conceitual expressa nos periódicos brasileiros. Caderno de Pesquisa do Programa de Pós-Graduação da Universidade Federal do Espírito Santo, v. 1, n. 1, p. 11-39, 1999.

COUTO, M. E.; LIMA, E. F. O curso TV na Escola e os desafios de hoje sob a ótica dos participantes. Revista Tecnologia Educacional, Rio de Janeiro, v. 31, n. 161/162, p. 89-99, abr./set. 2003.

DEMO, P. Conhecimento, tecnologia e formação dos professores das séries iniciais. Trabalho apresentado na 23ª Reunião Anual ANPEd, GT 13 - Ensino Fundamental, 2000.

DREIFUSS, R. A. A era das perplexidades: mundialização, globalização e planetarização: novos desafios. Rio de Janeiro: Vozes, 1996.

DUARTE, V. C. Capacitação docente em Minas Gerais e são Paulo: uma análise comparativa. Cadernos de Pesquisa, São Paulo, v. 34, n. 121, p. 139-168, jan/abr. 2004.

ESTATÍSTICAS do professor no Brasil. Brasília: Inep, 2003. Disponível em: <http://www.inep.gov.br/estatisticas/professor2003>. Acesso em: 14 jun. 2005

FRANCO, M. A.; CORDEIRO, L. M.; CASTILHO, R. A. F. D. O ambiente virtual de aprendizagem e sua incorporação na Unicamp. Educação e Pesquisa, São Paulo, v. 29, n. 2, p. 341-353, jul./dez. 2003.

FREITAS, H. C. L. Certificação docente e formação do educador: regulação e desprofissionalização. Educação G Sociedade, Campinas, v. 24, n. 85, p. 1095-1124, dez. 2003.

FURTER, P. Educação e vida. 12. ed. Petrópolis (RJ): Vozes, 1992.

GATTI, B. A. Formação continuada de professores: a questão psicossocial. Cadernos de Pesquisa, São Paulo, n. 119, p. 191-204, jul. 2003.

GONÇALVES, A. A. M. R. Educação à distância: ampliando caminhos para a formação de professores. Revista Tecnologia Educacional, Rio de Janeiro, v. 30, n. 156, p. 74-81, jan./mar. 2002.

GUERRA, A. F. S. Navegando em um ambiente de aprendizagem cooperativa para formação de professores em uma dimensão ambiental. 
Trabalho apresentado na 24ª Reunião Anual ANPEd, GT 16 - Educação e Comunicação, 2001.

LEITE, L. S.; TEIXEIRA, C. M. A educação a distância capacitando professores: em busca de novos espaços para a aprendizagem. Revista Tecnologia Educacional, Rio de Janeiro, v. 30, n. 152/153, p. 136-143, jan./jun. 2001.

LIBÂNEO, J. As políticas de formação de professores no contexto da reforma universitária: das políticas educativas para as políticas da educação. Revista Profissão Docente Online, Uniube/MG, v. 4, n. 12, 2004. Disponível em: <http://www.uniube.br/institucional/proreitoria/propep/mestrado/ educaao/revista/artigos.htm>. Acessado em: 9 jan. 2006.

LIMA, C. M. A formação contínua do professor e a educação a distância: conteúdos de representação social. Revista Tecnologia Educacional, Rio de Janeiro, v. 31, n. 157/158, p. 85-94, abr./set. 2002.

LIMA, C. M.; GRIGOLI, J.A. G.; BARROS, H. F. A educação a distância e o desafio da formação do professor reflexivo: um estudo sobre as possibilidades da EaD na formação pedagógica de professores universitários. Trabalho apresentado na 26a Reunião Anual ANPEd, GT 16 -Educação e Comunicação, 2003.UCDB

LITWIN, E. (Org.) Educação a distância: temas para o debate de uma nova agenda educativa. Porto Alegre: Artmed, 2001.

LOBO NETO, F. J. da S. EAD G formação de educadores: educação a distância. Revista Tecnologia Educacional, Rio de Janeiro, v. 30, n. 152/ 153, p. 69-80, jan./jun. 2001.

LOPES, E. M. T. Tendências teórico-metodológicas de pesquisa em história da educação. In: SEMINÁRIO HISTÓRIA DA EDUCAÇÃO BRASILEIRA: a ótica dos pesquisadores. 1994, Belo Horizonte. [Anais...]. Brasília: MEC/Inep, 1994. p. 19-27. (Série documental: Eventos, n. 5).

LÜDKE, M; ANDRÉ, M. E. D. A. Pesquisa em educação: abordagens qualitativas. São Paulo: EPU, 1986.

NÓVOA, A. Os professores na virada do milênio: do excesso dos discursos à pobreza das práticas. Educação e Pesquisa, São Paulo, v.25, n. 1, p. 1120, jan./jun. 1999.

OLIVEIRA, E. da S. G; NOGUEIRA, M. L. de L. Educação a distância e formação de professores; desafios e perspectivas. Revista Tecnologia Educacional, Rio de Janeiro, v. 31, n. 157/158, p. 95-103, abr./set. 2002. 
OLIVEIRA, E. G. Formação de professores a distância na transição de paradigmas. Trabalho apresentado na 26a Reunião Anual ANPEd, GT 08 - Formação de Professores, 2003a.

Formação de professores à distância na transição paradigmática Campinas (SP): Papirus, 2003b. (Coleção Magistério: Formação e Trabalho Pedagógico).

OLIVEIRA, L. M. P . Educação a distância: novas perspectivas à formação de educadores. In: MORAES, M. C. (Org.). Educação a distância: fundamentos e práticas. Campinas (SP): Unicamp Nied, 2002. p. 91-97.

Dialogia digital: em busca de novos caminhos à formação de educadores, em ambientes telemáticos. Trabalho apresentado na $27^{\mathrm{a}}$ Reunião Anual ANPEd, GT 08 - Formação de Professores, 2004.

PAIVA, J.; MACIEL, I. M. Redes cooperativas virtuais e formação continuada de professores: estudos para a graduação. Trabalho apresentado na 23ª Reunião Anual ANPEd, GT 16 - Educação e Comunicação, 2000 .

PEDROSA, S. M. P. A. A educação a distância na formação continuada do professor. Educar, Curitiba, n. 21, p. 67-81, 2003.

PEREIRA, E. P. Programando a tela nas amarras da arte de governar a distância: um estudo do "Curso de extensão TV na escola e os desafios de hoje". Trabalho apresentado na 25 a Reunião Anual ANPEd, GT 08 Formação de Professores, 2002.

PERRENOUD, P. Formação contínua e obrigatoriedade de competências na profissão de professor. In: BITAR, H. A. de F. et al. Idéias: sistemas de avaliação educacional. São Paulo: SESP, Fundação para o Desenvolvimento da Educação, Diretoria de Projetos Especiais, 1998. p.205-251.

PETERS, O. Didática do ensino a distância. São Leopoldo (RS): Unisinos, 2001.

PRETTI, O. A formação do professor na modalidade a distância: (des)construindo metanarrativas e metáforas. Revista Brasileira de Estudos Pedagógicos, Brasília, v. 82, n. 200/201/202, p. 26-39, jan./dez. 2001.

PRETTO, N. de L. Formação de professores exige rede! Revista Brasileira de Educação, Rio de Janeiro, n. 20, maio/ago. 2002.

QUALIS. Sistema de classificação de periódicos, anais e revistas. Brasília: Capes/MEC, 2003. Disponível em: < http://qualis.capes.gov.br>. Acesso em: 14 jun. 2005. 
SÁ, R. A. Educação à distância: considerações preliminares de um percurso na UFPR. Revista Tecnologia Educacional, Rio de Janeiro, v. 30, n. 152/ 153, p. 23-30, jan./jun. 2001.

SÁ, R. A. Licenciatura em pedagogia - séries iniciais do ensino fundamental na modalidade de educação a distância: a construção histórica possível na UFPR. Educar, Curitiba, n. 21, p. 173-204, 2003.

SCHÖN, D. A. Educando o profissional reflexivo: um novo design para o ensino e aprendizagem. Trad. Roberto Cataldo Costa. Porto Alegre: Artmed, 2000.

SILVA JÚNIOR, J. R. Reformas do Estado e da educação e as políticas públicas para a formação de professores a distância: implicações políticas e teóricas. Revista Brasileira de Educação, Rio de Janeiro, n. 24, set./dez. 2003.

SOARES, S. G. Inovações no ensino superior: reflexões sobre a Educação a Distância. In: CASTANHO, S.; CASTANHO, M. E. O que há de novo na educação superior: do projeto pedagógico à prática transformadora. Campinas (SP): Papirus, 2000. p. 221-238.

SOUZA, O. N. B.; OLIVEIRA, N. C. M. Irradiando o currículo: a proposta curricular do projeto rádio pela educação em análise. Trabalho apresentado na 26ª Reunião Anual ANPEd, GT 16 - Educação e Comunicação, 2003.

TOSCHI, M. S. Formação de professores e TV Escola. Trabalho apresentado na $23^{\text {a }}$ Reunião Anual ANPEd, GT 16 - Educação e Comunicação, 2000.

TRIGUEIRO, D. Um mundo novo, uma nova educação. Revista Brasileira de Estudos Pedagógicos, Rio de Janeiro, v. 51, n. 113, p. 9-18, jan./mar. 1969.

VILARINHO, L. R. Educação continuada e educação a distância: anomalias no contexto do paradigma tradicional de ensino? Trabalho apresentado na 24a Reunião Anual ANPEd, GT 04 - Didática, 2001.

VILARINHO, L. R.; BARRETO, R. B. R. Da tecnologia para além da tecnologia: a internet como possibilidade de redimensionamento do papel do professor. Trabalho apresentado na $27^{\mathrm{a}}$ Reunião Anual ANPEd, GT 04 - Didática, 2004.

ZEICHNER, K. M. A formação reflexiva de professor: idéias e práticas. Lisboa: Educa, 1993.

ZEICHNER, K. M.; DINIZ-PEREIRA, J. E. Pesquisa dos educadores e formação docente voltada para a transformação social. Cadernos de Pesquisa, v.35, n.125, maio/ago. 2005. 


\section{Anexo: Corpus da pesquisa}

ALMEIDA, M. E. B. Educação a distância na internet: abordagens e contribuições dos ambiente digitais de aprendizagem. Educação e Pesquisa, São Paulo, v. 29, n. 2, p. 327-340, jul./dez. 2003

BARRENECHEA, C. A. A formação da identidade do aluno na educação a distância: reflexões para um debate. Educar, Curitiba, n. 21, p. 117-131, 2003.

BARRETO, R. G. Tecnologia e educação: trabalho e formação docente. Educação G Sociedade, Campinas, v. 25, n. 89, p. 1181-1201, set/dez. 2004.

Tecnologias na formação de professores: o discurso do MEC. Educação e Pesquisa, São Paulo, v. 29, n. 2, p. 171-286, jul./dez. 2003.

Multimídias, organização do trabalho docente e políticas de formação de professores. Trabalho apresentado na 23ª Reunião Anual ANPEd, Sessão Especial, 2000.

BELINTANE, C. Por uma ambiência de formação contínua de professores. Cadernos de Pesquisa, São Paulo, n. 117, p. 177-193, nov. 2002.

BELLONI, M. L. Ensaio sobre a educação a distância no Brasil. Educação G Sociedade, Campinas, v. 23, n. 78, p. 117-142, abr. 2002.

A televisão como ferramenta pedagógica na formação de professores. Educação e Pesquisa, São Paulo, v. 29, n. 2, p. 287-301, jul./dez. 2003.

BRUNO, A. R. A linguagem emocional em ambientes telemáticos: tecendo a razão e a emoção nos cursos de formação. Trabalho apresentado na $25^{\mathrm{a}}$ Reunião Anual ANPEd, GT 16 - Educação e Comunicação, 2002

CARNEIRO, V. L. Q. Integração da TV na prática, na formação do professor: desejos, propostas, desconfianças, aprendizados. Trabalho apresentado na $26^{\text {a }}$ Reunião Anual ANPEd, GT 16 - Educação e Comunicação, 2003.

COUTO, M. E.; LIMA, E. F. O curso TV na Escola e os desafios de hoje sob a ótica dos participantes. Revista Tecnologia Educacional, Rio de Janeiro, v. 31, n. 161/ 162, p. 89-99, abr./set. 2003.

DEMO, P. Conhecimento, tecnologia e formação dos professores das séries iniciais. Trabalho apresentado na 23a Reunião Anual ANPEd, GT 13 - Ensino Fundamental, 2000

DUARTE, V. C. Capacitação docente em Minas Gerais e são Paulo: uma análise comparativa. Cadernos de Pesquisa, São Paulo, v. 34, n. 121, p. 139-168, jan/ abr. 2004.

FRANCO, M. A.; CORDEIRO, L. M.; CASTILHO, R. A. F. D. O ambiente virtual de aprendizagem e sua incorporação na Unicamp. Educação e Pesquisa, São Paulo, v. 29, n. 2, p. 341-353, jul./dez. 2003.

FREITAS, H. C. L. Certificação docente e formação do educador: regulação e desprofissionalização. Educação G Sociedade, Campinas, v. 24, n. 85, p. 10951124, dez. 2003. 
GATTI, B. A. Formação continuada de professores: a questão psicossocial. Cadernos de Pesquisa, São Paulo, n. 119, p. 191-204, jul. 2003.

GONÇALVES, A. A. M. R. Educação à distância: ampliando caminhos para a formação de professores. Revista Tecnologia Educacional, Rio de Janeiro, v. 30 n. 156, p. 74-81, jan./mar. 2002.

GUERRA, A. F. S. Navegando em um ambiente de aprendizagem cooperativa para formação de professores em uma dimensão ambiental. Trabalho apresentado na 24a Reunião Anual ANPEd, GT 16 - Educação e Comunicação, 2001.UNIVALI.

LEITE, L. S.; TEIXEIRA, C. M. A educação a distância capacitando professores: em busca de novos espaços para a aprendizagem. Revista Tecnologia Educacional, Rio de Janeiro, v. 30, n. 152/153, p. 136-143, jan./jun. 2001.

LIMA, C. M. A formação contínua do professor e a educação a distância: conteúdos de representação social. Revista Tecnologia Educacional, Rio de Janeiro, v. 31, n. 157/158, p. 85-94, abr./set. 2002.

LIMA, C. M.; GRIGOLI, J.A. G.; BARROS, H. F. A educação a distância e o desafio da formação do professor reflexivo: um estudo sobre as possibilidades da EaD na formação pedagógica de professores universitários. Trabalho apresentado na 26ª Reunião Anual ANPEd, GT 16 - Educação e Comunicação, 2003.UCDB

LOBO NETO, F. J. da S. EAD G formação de educadores: educação a distância. Revista Tecnologia Educacional, Rio de Janeiro, v. 30, n. 152/153, p. 69-80, jan./ jun. 2001.

OLIVEIRA, E. G. Formação de professores a distância na transição de paradigmas. Trabalho apresentado na 26a Reunião Anual ANPEd, GT 08 Formação de Professores, 2003a.

OLIVEIRA, E. da S. G; NOGUEIRA, M. L. de L. Educação a distância e formação de professores; desafios e perspectivas. Revista Tecnologia Educacional, Rio de Janeiro, v. 31, n. 157/158, p. 95-103, abr./set. 2002.

OLIVEIRA, L. M. P. Dialogia digital: em busca de novos caminhos à formação de educadores, em ambientes telemáticos. Trabalho apresentado na $27^{a}$ Reunião Anual ANPEd, GT 08 - Formação de Professores, 2004.

PAIVA, J.; MACIEL, I. M. Redes cooperativas virtuais e formação continuada de professores: estudos para a graduação. Trabalho apresentado na $23^{a}$ Reunião Anual ANPEd, GT 16 - Educação e Comunicação, 2000.

PEDROSA, S. M. P. A. A educação a distância na formação continuada do professor. Educar, Curitiba, n. 21, p. 67-81, 2003.

PEREIRA, E. P. Programando a tela nas amarras da arte de governar a distância: um estudo do "Curso de extensão TV na escola e os desafios de hoje". Trabalho apresentado na 25a Reunião Anual ANPEd, GT 08 - Formação de Professores, 2002.

PRETTI, O. A formação do professor na modalidade a distância: (des)construindo metanarrativas e metáforas. Revista Brasileira de Estudos Pedagógicos, Brasília, v. 82, n. 200/201/202, p. 26-39, jan./dez. 2001. 
PRETTO, N. de L. Formação de professores exige rede! Revista Brasileira de Educação, Rio de Janeiro, n. 20, maio/ago. 2002.

SÁ, R. A. Licenciatura em pedagogia - séries iniciais do ensino fundamental na modalidade de educação a distância: a construção histórica possível na UFPR. Educar, Curitiba, n. 21, p. 173-204, 2003.

SÁ, R. A. Educação à distância: considerações preliminares de um percurso na UFPR. Revista Tecnologia Educacional, Rio de Janeiro, v. 30, n. 152/153, p. 2330, jan./jun. 2001.

SILVA JÚNIOR, J. R. Reformas do Estado e da educação e as políticas públicas para a formação de professores a distância: implicações políticas e teóricas. Revista Brasileira de Educação, Rio de Janeiro, n. 24, set./dez. 2003.

SOUZA, O. N. B.; OLIVEIRA, N. C. M. Irradiando o currículo: a proposta curricular do projeto rádio pela educação em análise. Trabalho apresentado na 26ª Reunião Anual ANPEd, GT 16 - Educação e Comunicação, 2003.

TOSCHI, M. S. Formação de professores e TV Escola. Trabalho apresentado na 23ª Reunião Anual ANPEd, GT 16 - Educação e Comunicação, 2000.

VILARINHO, L. R. Educação continuada e educação a distância: anomalias no contexto do paradigma tradicional de ensino? Trabalho apresentado na $24^{\mathrm{a}}$ Reunião Anual ANPEd, GT 04 - Didática, 2001. UNESA

VILARINHO, L. R.; BARRETO, R. B. R. Da tecnologia para além da tecnologia: a internet como possibilidade de redimensionamento do papel do professor. Trabalho apresentado na 27ª Reunião Anual ANPEd, GT 04 - Didática, 2004. Unesa

Marta Lyrio da Cunha, mestre em Educação pela Universidade Estácio de Sá (Unesa), é professora do curso de graduação em Pedagogia da Universidade Gama Filho (UGF), Rio de Janeiro.

martalyrio@superig.com.br

Lúcia Regina Goulart Vilarinho, doutora em educação pela Universidade Federal do Rio de Janeiro (UFRJ), é professora do curso de mestrado em Educação da Universidade Estácio de Sá (Unesa).

lgvilarinho@netbotanic.com.br

Recebido em 17 de julho de 2006.

Aprovado em 7 de novembro de 2006. 